\title{
Experiences to be a family caregiver of dependent elderly in the home environment
}

\author{
Vivências de ser cuidador familiar de idosos dependentes no ambiente domiciliar
}

Alcimar Marcelo do Couto ${ }^{1}$, Edna Aparecida Barbosa de Castro ${ }^{2}$, Célia Pereira Caldas ${ }^{3}$

Objective: to understand the experience of caring for dependent elderly in the home environment, from the perspective of family caregivers that present burden and emotional distress. Methods: this is a qualitative research with a contribution in the Theory Grounded in Data. There were home visits for observation and semistructured interviews with nine relatives of dependent elderly in self-care. Results: with the coding and analysis of empirical data, one can understand the daily cares in the care relationship with their elderly dependent relatives. The consolidated experiences underlie on positive experiences, such as solidarity by the established interaction and the maintenance of self-esteem, and negative as changes in daily routine and health, with stress identification related to the caregiver role. Conclusion: in the understanding of the family, their experiences as a caregiver in the home context varied between positive and negative aspects, which respectively minimize and maximize the feeling of burden and emotional distress.

Descriptors: Caregivers; Aged; Nursing.

Objetivo: compreender as vivências de cuidar de idosos dependentes no ambiente domiciliar, a partir da ótica de cuidadores familiares que apresentam sobrecarga e desconforto emocional. Métodos: investigação qualitativa, com aporte na Teoria Fundamentada nos Dados. Realizaram-se visitas domiciliares para observação e entrevista semiestruturada com nove familiares de idosos dependentes em autocuidado. Resultados: com as codificações e análise do material empírico, pode-se compreender o cotidiano dos cuidadores na relação de cuidados com seus familiares idosos dependentes. As experiências consolidadas se embasam em vivências positivas, como a solidariedade pela interação estabelecida e a manutenção da autoestima, e negativas como mudanças na rotina de vida diária e na saúde, com identificação de tensão relacionada ao papel de cuidador. Conclusão: na compreensão dos familiares, as suas vivências como cuidador, no contexto domiciliar, variaram entre aspectos positivos e negativos, que respectivamente minimizam e maximizam o sentimento de sobrecarga e de desconforto emocional.

Descritores: Cuidadores; Idoso; Enfermagem.

\footnotetext{
${ }^{1}$ Hospital das Clínicas, Universidade Federal de Minas Gerais. Belo Horizonte, MG, Brazil.

${ }^{2}$ Universidade Federal de Juiz de Fora. Juiz de Fora, MG, Brazil.

${ }^{3}$ Universidade do Estado do Rio de Janeiro. Rio de Janeiro, RJ, Brazil. 


\section{Introduction}

To assume the task of caring for a dependent elderly at home has emerged as a growing phenomenon in Brazilian society since the late 1990s when the increase in the elderly population was configured. The care of the elderly is considered a duty of the family, in Brazilian culture, although sometimes does not show the adequate preparation, knowledge or support to perform this role. This duty becomes legal obligation by being contained in the Brazilian Federal Constitution and the Elderly Statute ${ }^{(1-2)}$.

What still exists, combining with the laws and public policy, is that, although the family assumes its role as a social institution and try to meet the care using their resources, does not have an institutional support to cope with this responsibility ${ }^{(2)}$. Thus, each family must build their informal system of care, which generates wear and stress, and may negatively affect the family as a whole ${ }^{(1)}$.

The presence of functional decline is related to the loss of autonomy and independence, limiting selfcare capacity, compromising the quality of life and generating dependency relationships that interfere with the processes of social interaction of the elderly. The disabling process corresponds to the evolution of a chronic condition involving various social, environmental, related to lifestyle, among others risk factors $^{(3)}$.

In the Brazilian cultural context, it is understood that elderly caregiver is the person that meets the needs arising from functional disability, temporary or permanent for self-care. This task includes actions aimed at helping the elderly, physically or mentally unable to perform practical tasks of daily living activities $^{(1,4)}$.

The process of caring for an elderly in a home context can impact the daily life of family caregivers and bring difficulties to emotional, physical, economic and social, with the consequent risk to their health and well-being ${ }^{(5)}$.

With the process of population aging and increasing incidence of non-communicable chronic diseases, the cognitive deficit and the loss of functional capacity, dependence on home care becomes progressive, thus becoming an important public health problem. Studious from the Gerontology Field describe the need to offer adequate conditions, such as infrastructure and support for the family exerts the role of caring for dependent elderly, properly ${ }^{(6-8)}$.

The elderly constitutes the segment of the population with worldwide fastest growing. Studies in the field of health care for the elderly that contribute to advances in knowledge about the experiences, difficulties and elderly and family needs are being encouraged by the National Research Agenda ${ }^{(9)}$ mainly related to the costs of caring process by the family under home care. In the gerontological nursing area, research has shown that there is a lack of publications that support the professional in training and support actions to family caregivers, and the impact of caring for disabled elderly in the home environment about informal caregivers is little explored by public policies. Thus, conducting studies and research in the Nursing area, centered on this theme, focusing on the elderly caregiver, especially the informal, show up as relevant, given the reality of the aging population and the growing demand for Health Systems by home care services to the elderly ${ }^{(2,4,7,10)}$.

The study complied with the formal requirements contained in the national and international regulatory standards for research involving human beings.

\section{Methods}

For understanding the proposed objective, the Theory Grounded in Data was used, as we consider relevant theorizing about the phenomenon, the context of life, and the experience of caring for dependent elderly at home, for family caregivers. In this method, the data were collected in the natural setting of occurrence of the studied phenomenon, with intrinsic relation of the analysis process with 
the theory that derives from them. We adopted the term theory, as to develop the theory of this approach means the process that is established through the work of generating concepts, to formulate ideas in logical, systematic and explanatory schemes, that the researcher has in constant interaction with the data $^{(11)}$.

Participating families of the research reside in the city of Juiz de Fora/Minas Gerais, which is an industrial, cultural and service center, of the southeast of Minas Gerais and central research office. The initial setting was the Geriatric and Gerontology Clinic of the University Hospital of the Federal University of Juiz de Fora. 78 elderly were evaluated through nursing consultation performed in the period from May to August 2012. All were accompanied by a relative and, after receiving guidance from the research, agreed to participate. Of these, 27 were classified with partially or important dependence for Daily Living Basic Activities, using the scale ${ }^{(12)}$. As they are identified, their main family caregivers were assessed about the level of burden and emotional discomfort by burden scales $^{(13)}$ and emotional distress detection - Self Reporting Questionnaire (SRQ-20)(14) and included into the second stage of the research, performed in their homes by agreement.

Home visits were scheduled by phone, at convenient times to family caregivers, followed by the order of visits, free of secondary criteria. The number of visited participants followed the theoretical saturation criterion proposed for the Theory Grounded in Data, i.e. data is collected until all categories are saturated ${ }^{(11)}$. Thus, nine main caregivers were visited, with the observation of their routine and conducting semi-structured interviews, led by guiding questions. By constant comparisons, a repetition in the responses, reactions and behaviors were observed, characterizing the saturation, i.e. there was no new or relevant data to justify the number of participants increasing.

In compliance with the method, which requires a constant comparison between the data, sometimes it took more than one home visit to the same participant. We elaborated a guiding script fieldwork, which occurred through the complementary techniques of observation and semi-structured interviews. Field notes, registered as topics in the field diary during the observation period, were later expanded. The transcripts of the interviews and pre-analysis were initiated after the expansion of the notes and before of the next interview, beginning the open, selective and axial coding processes, as methodological guidance ${ }^{(11)}$.

The empirical data were examined thoroughly in the analysis process, analyzing line by line, paragraph by paragraph to extract the first codes, and each stretch that featured a phenomenon was marked and coded with a term to represent it. The identified codes by the process of comparison, were grouped by similarities and differences forming subcategories. With the advancement of analysis, categories were constructed, recoded, combined and compared. The last phase sought to identify the central category, determining and validating its relation to other categories and among them ${ }^{(11)}$. In this sense, the central category consisted of: "The experiences of being a caregiver of dependent elderly" and was composed of three subcategories, positive aspects experienced by family caregivers; negative aspects experienced by family caregivers; the stress of caregiver role.

The research was approved by the Ethics Committee on Human Research of the University Hospital of the Federal University of Juiz de Fora. In the results presentation, the participants' anonymity was assured, since the main family caregivers were identified by codenames.

\section{Results}

The nine caregivers participant in the study were female, married or with a stable civil union, had less than eight years of education, aged between 43 and 84 years and about the kinship degree with the elderly, six were daughters, two daughters-in-law, and one wife. All caregivers showed emotional distress, 
and when analyzing the burden degree of the family in the performance of activities involving the elderly care dependent at home, it was found that seven caregivers evaluated the burden as moderate to severe and two caregivers as a moderate burden.

In the understanding of the participants, their experiences as caregivers of dependent elderly in the home context, present "positives" and "negatives" aspects, which respectively minimize and maximize the feeling of burden and emotional distress in their daily lives.

\section{Positive aspects experienced by family caregivers}

Regarding experiences, facilitators feelings are emphasized, about the dependent family member, the moments of interaction between caregiver and dependent elderly, and maintaining self-esteem in situations of difficulty and commitment of their health conditions of family caregivers.

The caring relationship is surrounded by various feelings, reflecting the daily lives of caregivers, whether of difficulties and suffering or overcoming and motivation. Among feelings considered as positive in the relationship of care, were found affection for the family, solidarity, gratification, appreciation of their actions, commitment, and well-being. So, it's a commitment that we took from the heart, not an obligation. You have done and are doing because you like the person. On the positive side, I will say that is the love and affection (Safira). I help to be later helped too (Rubi).

One of the caregivers highlighted the positive feelings involved in the care relationship, such as solidarity and was so much identified with the role, that even in the absence of the mother dependent of care, after her death, she intended to continue developing these activities in a voluntarily way, to help others. So if I treat her with love, just as I treat her, I might be dealing with other people. Because I think that when I do not have my mother anymore, I will be voluntary, I'll give a little of myself to those people who need care (Tourmaline).

In addition to these positive feelings identified in everyday families, there was an aspect related to moments of interaction between caregiver and elderly in the care relationship that contributed to the caregiving role be more rewarding and they felt valued, for realizing the importance and the need for performed actions. The cool thing is that every morning, when I give the coffee, she says thanks God, after lunch, also says thanks God. It is these little things that we know we are taking her from this situation that she lives today (Safira). Today, I was giving yogurt to her in the morning, and she was laughing at me. I asked: Do you like it? She said: yes. That makes me feel good (Jade).

Another finding aspect was that caregivers were carrying with them some values and customs related to the role of the family when taking care of their elderly relative. In the following speech, the maintenance of the family caregiver self-esteem is evident. I joke like this: Multiple sclerosis is an opponent, I'm a team, and she is another one. So, sometimes it was one by one, sometimes zero by zero. Sometimes when I was very ill, alone at home, I said: 'today is one to zero for you, but tomorrow the time I wake up I equalize this game.' Then I stayed all the night, sometimes I was able, sometimes not, then I say: it is still one to zero, but tomorrow I win you. And I was always joking, to improve (Cristal).

\section{Negative aspects experienced by family caregivers}

The negative aspects experienced by the main caregiver can be understood as a set of changes in their lives, from the moment it was necessary to take care of the dependent family elderly. In this context caregivers reported the occurrence of the work abandonment to take care, the emotional life came to occupy a secondary place, the commitment of social activities, especially leisure and changes in health disease process, which could be observed in damage reports of health conditions, difficulties in relation to sleep and rest and constant presence of negative feelings in their daily lives.

The abandonment of work to care was evident in the excerpts of the following speeches: I worked out, but then after she began to look like this, my sister said: You better leave, I worked in a family house because we work concerned about 
all these things. (Pérola). I worked out; I had to leave as well. So I stopped everything because of her. But do not regret (Turmalina).

The leisure deficiency was present in the lives of caregivers when there was observed the realization of a few social activities in their daily life routine or even abandoned altogether these activities. Caregivers, to fulfill their roles, failed to exercise activities they liked and were part of their socio-cultural context, like traveling, fishing, nightlife, going to church or visit friends, which featured a deficit leisure by these families. It changed. A lot. Regarding leisure, during the period that my mother is sick here, we do not go out anymore, anywhere (Esmeralda). I like to go to the church. I love to be with my family. I like fishing, traveling, that I cannot do it anymore. I loved to travel, traveling twice a year. That's what happened (Safira).

We note that some caregivers, to priority family care activities and perform their functions without interruption, also leave the affective life in a second place. And the emotional part, to date, I have no boyfriend, because I will not give up my mother. Maybe today if I had married, I would not even be married anymore, because some accept, helps to care, but that's full-time of the person. So husband would not accept, as I would ... (Turmalina).

The emotional every day of the family caregiver's life is also permeated by negative feelings. Among these feelings emphasize the anguish, sadness, anxiety, guilt, remorse, irritability, and nervousness. It's all; it's all... I think if I only take care of her would be easier, of course, for sure. Then I feel that anguish, I have to do this, I have to do that, and I can't do it because of her, this is very bad. I feel very sad (Jade). And also, give a chance for the person because I have a fault that is to have not left my brothers like this, helping me to take care of my mother and my father. Because nowadays, they can't speak, I did everything for my father and my mother (Safira).

When reporting about their livings in the care process, the family caregiver highlighted the commitment of their health. Some caregivers have lived or went to live with chronic processes that require permanent care, professional monitoring or the use of medicaments.

The repercussions of everyday care with the elderly relative, in the health status of caregivers became clear in the speeches, where it is observed the development of a hypertensive framework, changes such as a headache and backache and also expressions indicating the presence of depression. I'm taking fluoxetine again, I had given a stop because I did not want to become dependent on medicine, but I had to re-take because my blood pressure was rising. Emotional. I was feeling tachycardia, anxiety, and lack of air... (Jade). I have a lot of headaches that I get to cry. Sometimes I feel like a burning in the neck. It hurts, but I can't even explain. The column pain hinders me, and I can't turn down because I can fall (Rubi). Also, I said: if you call me today to go to a party, gives me sadness, I want to cry... I can't go to a party. I can't, a party for me is sadness (Pérola).

Among the changes of the health state of caregivers, a condition that repeats in their reports is the change in the sleep and rest pattern. We verified difficulties to meet this physiological need of every human being, important to preserve the ability to perform daily activities and comply with the heavy routine of care. Oh, this I have untill today. I have much difficulty to sleep. I don't use remedy because I do not want to be dependent on it (Esmeralda). I'm already bad for sleep, so now it worst. Because I'm already very attentive on her, anything she could fall. I'm getting very anxious with this (Pérola). And today I sleep in her room, and then every turn she gives, any groan, I'm already aware (Turmalina).

\section{Stress of caregiver role}

Among the activities performed by family caregivers, some like bath, intimate hygiene, diaper change, transfer and position changes, were the tasks that cause most physical burden. A worrying aspect is that they daily care, most of the cases without interruption, without the help of other family members and without physical structure and equipment suitable to provide such care. If I give the bath, give me fatigue, and then I go to bed. I can't carry her alone; I can't turn her in bed alone (Cristal). So I asked the doctor to get a hospital bed, higher, to change a diaper, give a bath in bed and these things. Because it is already difficult, I am feeling a back pain (Esmeralda).

The emotional burden was observed through signs and symptoms such as: irritability, nervousness, stress, sadness, crying, anguish, and stress, among 
others. This emotional burden was evident in the speeches of interviewed who reported one or more of these signs and symptoms. Affect yes, affects a lot. Today I am more depressed. Then sometimes I feel a revolt when I see I already start to cry. So, I mean, I was more depressed because of it (Turmalina). Yes, especially now in this period I felt. I felt a lot. Tense, extremely stressed, because I was talking to people and people did not hear me. And I went into stress and tension (Cristal).

Fatigue and stress were often expressed by family caregivers, through irritability and feelings of sadness, isolation, frustration and anguish. One consequence of the presence of emotional burden and consequently stress on the caring role in families' daily lives, is losing patience with risk for violence against the elderly. I've been too scared to lose control with it. Dread. Because there is a time to do something with us. I've been too scared. And there are times that she makes people nervous (Pérola).

Besides the loss of patience as a risk to violence against dependent elderly, another burden repercussion of caregiver role was the deficitidentified in the self-care of the elderly caregiver. Before an activity accumulation of daily life, lack of support from other family members and their health care, the caregiver prioritizes care to family dependent. So they stop attending beauty salon, doing nails, hair and even their health. Oh! I do not care for me like I cared. I always did nail, hair but not today. It is once a month, or when I can. I do not take care anymore. Today I'm staying here taking care of her (Turmalina). Oh, I am diabetic... There are one year and two months now that I don't go to "the doctor" (Esmeralda).

\section{Discussion}

The experience of positive feelings by caregivers is an important aspect that needs to be identified and valued, as are critical to maintaining the emotional ties between family caregivers and dependent elderly. Besides contributing to this feel recognized in the performance of their duties and allowed them to relieve stress in the played role. However, through integrative review it was found that in general the content of the studies covers aspects relating to the onus of care, failing to highlight the positive aspects of care relationship ${ }^{(4)}$.

In addition to the affection and interaction ties between caregiver and the dependent elderly serve as a positive stimulus that facilitated the achievement of care and could relieve caregiver stress, another identified important factor was the caregiver selfesteem maintenance capacity in the face of difficulties and limitations in everyday care.

It is stressed that the number of positive aspects, found in the relationship of care established within the family must be recognized, respected and valued by nurses and other professionals, during guidance and support measures established to assist the family to maintain and strengthen positive feelings, interaction in the relationship of care and maintenance of the caregiver self-esteem, promoting the mutual well-being.

Furthermore, the study revealed that the task of caring for a dependent elderly, with their difficulties in carrying out hygiene, feeding and even the management of behavioral disorders, demanded the caregiver almost exclusively dedicated, causing interruption of their activities to the detriment of care provided to the relative. Some caregivers came to quit their jobs and occupations, putting their selfcare in second place, with the precariousness of their relationship and began to experience social isolation.

The observation of daily life of elderly caregivers, provided then to realize that caring is an absorbing task, and that causes many changes in their lives after assuming such a role; related, in addition to job abandonment and its economic impacts on family dynamics, the lack of time for exercise of social activities, especially leisure. Caregivers take care of the other and do not realize the need to care themselves, abandoning the social life. This lack of leisure, in addition to confinement in a caring environment, generates burden feelings ${ }^{(15-16)}$.

The caregiver, playing their role, experience restrictions about their life, as they come to dealing with the prospect of greater social isolation, lack 
of time for themselves and contact with family and friends, with possible interruptions in their professional careers and negligence in the care of their health ${ }^{(8,10,17)}$.

The presence of negative feelings reinforces the need for nursing interventions seeking help to overcome this situation, which directs to an impediment context, that contributes to rising levels of burden and emotional distress, that compromise the socio-cultural well-being, both the family as the dependent care elderly. Living together with these feelings, even for short periods, is detrimental to the quality of life and caregiver health conditions ${ }^{(4)}$.

It was identified that the family caregiver recognized that their health was suffering negative impacts, been compromised by the care process, but given the context of so many demands and care needs of the elderly, seemed to feel unable to seek change mechanisms.

Concerning health and illness process of family caregivers, it was found that caregivers were exposed to various types of prolonged stressors and, therefore, also presented the risk of having health problems similar to the person who needs care. Even the most resilient are subject to physical and emotional burden, being routinely tested their ability to cope situations inherent to care $^{(18-19)}$. We reinforce these findings and agree likewise, that the caregiver presented restrictions in their life, assuming to take care and, consequently, could become a potential customer, who also needed care.

We also corroborate the premise that when the family performs the care tasks without guidance and support of health services, this may compromise their health and thus, pass to also need care, as a result, of burden and emotional stress that could be avoided or minimized $^{(2)}$.

When analyzing the health-disease process of the family caregiver, we understand that maintaining their health is of fundamental importance for the continued realization of care to a dependent family member. In addition to the learning of technical care and procedures, caregivers must learn to reconcile the care given to dependent family member, with the necessary measures for maintaining their health and well-being $^{(8)}$.

Among the situations reported by family members who may be related to the difficulty in establishing a pattern of effective sleep are the permanence of the caregiver in the same bed or in the same environment of the elderly, and the apprehension of 'happening something bad' to the elderly and the caregiver may not realize by the fact of being asleep.

These situations direct to the need to establish an alternation routine between family members, allowing the primary caregiver alternate care nights with other members so that they can restore their rest and rest needs. However, this strategy is not yet part of everyday life of most families. There is a great weakness in the family and formal support for the alternation $\operatorname{care}^{(8)}$.

The stress of the caregiver role is included among the nursing diagnosis proposed by NANDA taxonomy (North American Nursing Diagnosis Association). It is defined as the "state in which the individual is experiencing physical, emotional, social and/or financial burden in the process of care another person"(18:158).

Among the stress attributes of the family caregiver of dependent elderly, the biopsychosocial changes that the family suffered have been raised and concluded that family caregivers show changes in physical, emotional conditions, an imbalance between activity and rest and compromised individual coping $^{(19)}$.

The influence of the life and health status, resulting from the activities and care for dependent elderly, could be observed in objective and subjective impacts. An influence that generates goal impact can be noticed from practical problems of the caregiver's daily life, as their family relations, changes in the employment and income fields, illnesses or aggravations in health status and reducing social activities. On the other hand, the subjective refers 
to the family caregiver's emotional reaction to the routine care of the elderly. Thus, the reported physical burden in the performance of activities of caregivers was added, another element that also characterized the stress diagnostic of caregiver role: the emotional burden.

The family caregiver living together with the stress state is often subject to the emergence of situations that encourage them to lose patience in the daily rhythm of caring, contributing to an increased risk of domestic violence against the elderly ${ }^{(4)}$.

It becomes even more important the search for support strategies and support families living together with dependent elderly, and must play the role of caregiver, with the objective to minimize the burden levels, of emotional and stress discomfort, promoting an environment that meets the needs of the elderly and families, contributing to the establishment of an intra-family dynamic that is free of risk factors for violence and neglect.

Another worrying aspect seen in livings of family caregivers was that the deficit in the practice of self-care was mainly related to difficulties in reconciling self-care with the care activities of the dependent elderly.

The nurse has skills and abilities in their professional environment that contribute to such difficulties to be overcome, and thus families achieve their self-care goals, as caregivers of a family dependent. This professional "can identify individuals at high risk of going into stress related to caregiving role, helping them to prevent this serious situation"(18: 159).

Therefore, it is important to know the informal caregivers, considering their sociocultural particularities, difficulties, limitations, and perceptions, to provide subsidies for the development of care and support services, with planning nursing actions that target the real needs of dependent elderly and their families ${ }^{(8)}$. Moreover, it is not only the technical preparation that the caregiver needs, but also the maintenance and promotion of their health, through projects, which intervened in the care with them and considered suffered burden, whether physical, mental, financial or social ${ }^{(20)}$.

\section{Final Considerations}

The results obtained with this investigation, enable to identify that, in the understanding of the participants, their experiences as a caregiver in the home context, ranged between positive and negative aspects, which respectively minimize and maximize the feeling of burden and emotional distress.

Regarding the positive experiences, facilitator's feelings were emphasized about the dependent family member, the moments of interaction between caregiver and dependent elderly and maintaining self-esteem in the face of difficult situations. As for the negative experiences, abandonment of work to care was identified, affective life occupying second place, the commitment of social activities, especially leisure and changes in health and disease process, and a constant presence of negative feelings in the care routine.

The findings of this research contribute to give visibility to the need for family support for the elderly that need of home care, in the context of public policy. The experiences understanding and family difficulties on care demands may encourage health staff to obtain solvability in home care to dependent elderly. Also contribute to rethink in the context of the health work organization, especially the teams of the Family Health Strategy, rising health education activities, such as community groups, support and holder, teaching selfcare, and home visits, which include compliance with the health needs of caregivers, helping to reduce the stress experienced in their daily lives. 


\section{Collaborations}

Couto AM participated in the project elaboration, collection, and analysis of data and writing of the article. Castro EAB participated in the project elaboration, data analysis and writing of the article. Caldas CP contributed to the elaboration of the article and final approval of the version to be published.

\section{References}

1. Lindolpho MC, Caldas CP, Acioli S, Vargens OMC. $O$ cuidador de idoso com demência e a política de atenção à saúde do idoso. Rev Enferm UFPE On line. 2014[citado 2015 Jun 26]; 8(12): 438190. Disponível em: http://www.revista.ufpe.br/ revistaenfermagem/index.php/revista/article/ view/6783/pdf_6794

2. Vieira CPB, Fialho AVM, Moreira TMM. Dissertações e teses de enfermagem sobre o cuidador informal do idoso, Brasil, 1979 a 2007. Texto Contexto Enferm. 2011; 20(1):160-6.

3. Ministério da Saúde (BR). Secretaria de Atenção à Saúde, Departamento de Atenção Básica. Envelhecimento e Saúde da pessoa Idosa. Brasília: Ministério da Saúde; 2007.

4. Oliveira DC, D’Elboux MJ. Estudos nacionais sobre cuidadores familiares de idosos: revisão integrativa. Rev Bras Enferm. 2012; 65(5):829-38.

5. Vieira CPB, Fialho AVM, Freitas CHA, Jorge MSB. Práticas do cuidador informal do idoso no domicílio. Rev Bras Enferm. 2011; 64(3):570-9.

6. Barbosa RL, Morais JM, Resck ZMR, Dázio EMR. Home caregiver of elderly patients with Alzheimer's disease. Rev Rene. 2012; 13(5):11916.

7. Gratão ACM, Vendruscolo TRP, Talmelli LFS, Figueiredo LC, Santos JLF, Rodrigues RAP. Sobrecarga e desconforto emocional em cuidadores de idoso. Texto Contexto Enferm. 2012; 21(2):304-12.
8. Seima MD, Lenardt MH, Caldas CP. Relação no cuidado entre o cuidador familiar e o idoso com Alzheimer. Rev Bras Enferm. 2014; 67(2):233-40.

9. Ministério da Saúde (BR). Secretaria de Ciência, Tecnologia e Insumos Estratégicos, Departamento de Ciência e Tecnologia. Agenda nacional de prioridades de pesquisa em saúde; Brasília: Ministério da Saúde; 2008.

10. Costa SRD, Castro EAB. Autocuidado do cuidador familiar de adultos ou idoso dependentes após a alta hospitalar. Rev Bras Enferm. 2014; 67(6):97986.

11. Strauss A, Corbin J. Pesquisa qualitativa: técnicas e procedimentos para o desenvolvimento de teoria fundamentada. Porto Alegre: Artmed; 2008.

12. Lino VTS, Pereira SEM, Camacho LAB, Ribeiro Filho ST, Buksman S. Adaptação transcultural da escala de independência em atividades da vida diária (Escala de Katz). Cad Saúde Pública. 2008; 24(1):103-12.

13. Scazufca M. Brazilian version of the Burden Interview Scale for the assessment of care in carers of people with mental illnesses. Rev Bras Psiquiatr. 2002; 24(1):12-7.

14. Mari JJ, Williams P. A validity study of a psychiatric screening questionnaire (SRQ-20) in primary care in the city of São Paulo. Br J Psychiatry. 1986; 148:23-6.

15. Lindolpho MC, Oliveira JB, Sá SPC, Brum AK, Valente GSC, Cruz TJP. 0 impacto da atuação dos enfermeiros na perspectiva dos cuidadores de idosos com demência. Rev Pesqui Cuid Fundam Online [periódico na Internet]. 2014 [citado 2015 jun 22];6(3):1078-89. Disponível em: http://www. seer.unirio.br/index.php/cuidadofundamental/ article/view/3452/pdf_1360

16. Pedreira LC, Oliveira AMS. Cuidadores de idosos dependentes no domicílio: mudanças nas relações familiares. Rev Bras Enferm. 2012; 65(5):730-6.

17. Carvalho DP, Toso BRGO, Viera CS, Garanhani ML, Rodrigues RM, Ribeiro LFC. Caregivers and implications for home care. Texto Contexto Enferm. 2015; 24(2):450-8. 
18. Carpenito-Moyet LJ. Diagnósticos de enfermagem: aplicação à prática clínica. Porto Alegre: Artmed; 2009.

19. Fernandes MGM, Garcia TR. Tension attributes of the family caregiver of frail older adults. Rev Esc Enferm USP. 2009; 43(4):818-24.
20. Pereira MJSB, Filgueiras MST. A dependência no processo de envelhecimento: uma revisão sobre cuidadores informais de idosos. Rev APS. 2009; 12(1):72-82. 